\title{
An industry wide mortality study of chemical workers occupationally exposed to benzene. II Dose response analyses
}

\author{
O WONG
}

From Environmental Health Associates, Inc, Oakland, CA 94607, USA

ABSTRACT The data presented in this paper show statistically significant dose response relation between cumulative exposure to benzene (ppm-months) and mortality from both all lymphopoietios cancer combined and leukaemia. Chemical workers with a cumulative exposure to benzene of at leasis $720 \mathrm{ppm}$-months experienced a relative risk of 3.93 for lymphatic and haematopoietic cancer whef compared with workers with no occupational exposure. The dose response relation between cumur lative exposure and non-Hodgkin's lymphopoietic cancer was of borderline statistical significanc $\vec{\varepsilon}$ $(p=0 \cdot 06)$. No dose response relation was detected for any other causes of death.

In part I of this report were listed several issues regarding the epidemiological relation between exposure to benzene and lymphatic and haematopoietic cancers. It was pointed out that, among other things, none of the studies reviewed provided adequate information on exposure to benzene for any dose response analysis.

The study design and the general results of a cohort study of chemical workers exposed to benzene were given. Exposure information in terms of eight hour time weighted averages (TWA) and peak exposure was available. In part II here are presented dose response analyses by latency, duration of exposure, cumulative exposure (ppm-months), and peak exposure for several types of lymphatic and haematopoietic cancers. Epidemiologically, a positive dose response relation adds strength to the association between exposure to benzene and lymphatic and haematopoietic cancer.

\section{Methods and materials}

A detailed description of the cohort is given in part I of this report. Briefly, it consisted of a group of male chemical workers from seven plants who were occupationally exposed to benzene for at least six months between 1946 and 1975 and a comparison group of male chemical workers from the same plants who were employed for at least six months during the same period but were never occupationally exposed to Accepted 5 August 1986 benzene. Jobs with exposure to benzene were classifie into two categories: continuous exposure and inter mittent exposure.

The exposed group consisted of 4602 chemica workers; 3536 were continuously exposed (some wit $\$$ intermittent exposure as well) and 1066 were intermit tently exposed. The comparison group consisted of 3074 chemical workers from the same plants but wit no occupational exposure to benzene. For the 767 workers in the total cohort, vital status follow up untif 31 December 1977 showed that $6463(84 \cdot 20 \%)$ were alive, $1036(13 \cdot 50 \%)$ had died, and $177(2 \cdot 31 \%)$ were of unknown status. Among those identified as dead death certificates were obtained for $1013(97.8 \%)$. Underlying causes of death were coded according to the 8th revision of the International Classification of Diseases. Cause specific mortality analyses were base on the standardised mortality ratio (SMR) using the United States population as comparison ${ }^{2}$ or the. Mantel-Haenszel chi-square and the corresponding relative risk (RR) using the group with nR occupational exposure as comparison. ${ }^{3}$ In part II, iR addition to SMR analysis, dose response analysis based on the extension of the Mantel-Haenszel pro cedure with internal comparison was also conducted This procedure, which tests for a progressive trend $b \bar{\Phi}$ exposure groups without any assumption of the shape of the dose response relation (thus avoiding problem? of non-linearity), is particularly appropriate, given the्ठ amount of imprecision in the historical exposure dat in this study. 
Exposure classification of jobs

\section{CONTINUOUS CATEGORY}

The continuous category consisted of jobs in which a worker was assigned to a discrete area in which benzene was produced, separated, recovered, processed, or loaded/unloaded, and potential exposure to benzene occurred on at least three days a week. These jobs were further categorised on the basis of eight hour TWA (time weighted average) and peak exposure to benzene (without regard to use of respirators) as follows:

$\begin{array}{lr}\text { Eight hour TWA } & \\ \text { Low } & <1 \mathrm{ppm} \\ \text { Medium } & 1-10 \mathrm{ppm} \\ \text { High } & 11-50 \mathrm{ppm} \\ \text { Very high } & >50 \mathrm{ppm} \\ \text { Peak } & \\ \text { Low } & <25 \mathrm{ppm} \\ \text { Medium } & 25-100 \mathrm{ppm} \\ \text { High } & >100 \mathrm{ppm}\end{array}$

Specifically, this category included, in addition to other groups

(1) Maintenance people assigned specifically to a benzene unit and

(2) Laboratory quality control workers if they were assigned to samples from benzene units only.

\section{INTERMITTENT CATEGORY}

The intermittent category could also be described as "casual" exposure to benzene. It encompassed those jobs in which a worker was not assigned to a discrete area where benzene was produced, separated, recovered, processed, or loaded/unloaded; however, the job required that the worker periodically worked in these areas, the pattern of which could not be characterised as continuous. These jobs were further divided into three exposure groups (without regard to the use of respirators) as follows:

$\begin{array}{lr}\text { Peak } & <25 \mathrm{ppm} \\ \text { Low } & 25-100 \mathrm{ppm} \\ \text { Medium } & >100 \mathrm{ppm}\end{array}$

Specifically, this category included, in addition to other groups

(1) Maintenance people assigned on a plant wide basis.

(2) Laboratory quality control workers only if they served both benzene and non-benzene units.

(3) Workers assigned to loading/unloading where benzene was handled regularly but infrequently-for example, if barge loading was once a month.

The classification of each job by exposure was based on a uniform task approach, similar to the procedure proposed by Esmen. ${ }^{5}$ A group of industrial hygienists from the participating companies who were familiar with the plant operations derived a list of 34 uniform tasks. Based on both job and location description, as well as a consideration of calendar time periods, each job encountered in the study was broken down into these 34 uniform tasks and the corresponding amount of time spent at each task. Based on available industrial hygiene measurements (current and past), changes in production and process modifications, a concentration level of benzene exposure was estimated for each task. Therefore, the exposure level for a particular task might change over time. An eight hour TWA for each job could be obtained by summing the products of the proportion of the time at each uniform task and the corresponding benzene concentration. It was thought that this uniform task approach was useful, since it provided a procedure for the industrial hygienists to consider carefully the exposure level associated with each particular task. It should be emphasised here that industrial hygiene data for some plants were limited before 1970.

Two plants did not use the uniform task approach to estimate exposure levels. At one (plant 6), jobs as indicated on previous employment records were not specific enough for exposure classification. The employment records were reviewed by long term supervisors and coworkers, however, and exposure levels were estimated by supervisors who had worked in the exposed department. At the other (plant 7), only a few individuals were exposed at the units included in the study. Work histories were not specific enough for exposure classification, and these individuals were identified through old medical records and lists of names included in a benzene monitoring programme. Their exposure levels were estimated by a long term industrial hygienist who based his determination primarily on area measurements.

\section{Exposure classification of cohort members}

Cohort members were classified into three categories according to their occupational benzene exposure histories - that is, their jobs before the end of the coded work histories:

Table 1 Distribution by cumulative exposure (ppm-months) of cohort members in the continuous exposure group

\begin{tabular}{lcc}
\hline Cumulative exposure (ppm-months) & Frequency & $\%$ \\
\hline$<180$ & 1809 & $51 \cdot 16$ \\
$180-719$ & 1047 & $29 \cdot 61$ \\
$\geqslant 720$ & 680 & $19 \cdot 23$ \\
Total & 3536 & $100 \cdot 00$ \\
\hline
\end{tabular}


Table 2 Distribution by maximum peak occupational exposure to benzene and exposure group

\begin{tabular}{|c|c|c|c|c|c|c|}
\hline \multirow[b]{2}{*}{ Maximum peak } & \multicolumn{2}{|c|}{ Intermittent exposure } & \multicolumn{2}{|c|}{ Continuous exposure } & \multicolumn{2}{|l|}{ Total } \\
\hline & Frequency & $\%$ & Frequency & $\%$ & Frequency & $\%$ \\
\hline $\begin{array}{l}<25 \mathrm{ppm} \\
25-100 \mathrm{ppm} \\
>100 \mathrm{ppm}\end{array}$ & $\begin{array}{l}336 \\
114 \\
616\end{array}$ & $\begin{array}{l}31 \cdot 52 \\
10 \cdot 69 \\
57 \cdot 79\end{array}$ & $\begin{array}{r}413 \\
1272 \\
1851\end{array}$ & $\begin{array}{l}11.68 \\
35.97 \\
52.35\end{array}$ & $\begin{array}{r}749 \\
1386 \\
2467\end{array}$ & $\begin{array}{l}16 \cdot 28 \\
30 \cdot 12 \\
53 \cdot 61\end{array}$ \\
\hline
\end{tabular}

Table 3 Distribution by duration of occupational exposure to benzene and exposure group

\begin{tabular}{|c|c|c|c|c|c|c|}
\hline \multirow[b]{2}{*}{ Years of exposure } & \multicolumn{2}{|c|}{ Intermittent } & \multicolumn{2}{|l|}{ Continuous } & \multicolumn{2}{|l|}{ Total } \\
\hline & Frequency & $\%$ & Frequency & $\%$ & Frequency & $\%$ \\
\hline $\begin{array}{l}<1 \\
1-4 \\
5-9 \\
10-14 \\
15-19 \\
20-24 \\
25-29 \\
30-34 \\
\geqslant 35\end{array}$ & $\begin{array}{r}182 \\
377 \\
145 \\
79 \\
76 \\
77 \\
66 \\
50 \\
14\end{array}$ & $\begin{array}{r}17 \cdot 07 \\
35 \cdot 37 \\
13 \cdot 60 \\
7 \cdot 41 \\
7 \cdot 13 \\
7 \cdot 22 \\
6 \cdot 19 \\
4 \cdot 69 \\
1 \cdot 31\end{array}$ & $\begin{array}{r}334 \\
1212 \\
590 \\
414 \\
271 \\
263 \\
320 \\
107 \\
25\end{array}$ & $\begin{array}{r}9.45 \\
34.28 \\
16.69 \\
11.71 \\
7.66 \\
7.44 \\
9.05 \\
3.03 \\
0.71\end{array}$ & $\begin{array}{r}516 \\
1589 \\
735 \\
493 \\
347 \\
340 \\
385 \\
157 \\
39\end{array}$ & $\begin{array}{r}11.21 \\
34.53 \\
15.97 \\
10.71 \\
7.54 \\
7.39 \\
8.39 \\
3.41 \\
0.85\end{array}$ \\
\hline Total & 1066 & $100 \cdot 00$ & 3536 & $100 \cdot 00$ & 4602 & $100 \cdot 00$ \\
\hline
\end{tabular}

Continuous exposure-Those with jobs totalling at least six months in either the continuous or intermittent group and at least one job, regardless of duration, in the continuous group.

Intermittent exposure-Those with jobs totalling at least six months in the intermittent group only.

Comparison (no occupational exposure)-Those who never had any exposed (continuous or intermittent) jobs.

For each cohort member in the continuous exposure group, a cumulative exposure index in terms of ppm-months was calculated by summing the products of eight hour TWA and duration of all continuously exposed jobs since first exposure until the

Table 4 Distribution by age at first occupational exposure to benzene

\begin{tabular}{lcr}
\hline Age at first exposure to benzene & Frequency & $\%$ \\
\hline$<20$ & 122 & $2 \cdot 65$ \\
$20-24$ & 1206 & $26 \cdot 21$ \\
$25-29$ & 1256 & $27 \cdot 29$ \\
$30-34$ & 805 & $17 \cdot 49$ \\
$35-39$ & 539 & $11 \cdot 71$ \\
$40-44$ & 306 & 6.65 \\
$45-49$ & 176 & 3.82 \\
$50-54$ & 116 & $2 \cdot 52$ \\
$55-59$ & 53 & $1 \cdot 15$ \\
$60-64$ & 22 & 0.48 \\
$65-69$ & 0 & $0 \cdot 00$ \\
$70-74$ & 0 & 0.00 \\
$75-79$ & 1 & 0.02 \\
Total & & $100 \cdot 00$ \\
\hline
\end{tabular}

end of work history coding. Table 1 shows the numberf of cohort members by their cumulative exposure index. Three cumulative exposure groups were cors structed: $<180,180-719$, and $\geqslant 720$ ppm-month The first level, $180 \mathrm{ppm}$-months, is equivalent to long term exposure of $0.5 \mathrm{ppm}$ for 30 years or $1 \mathrm{ppm}$ for 15 years, and so on. It should be emphasised tha $180 \mathrm{ppm}$-months can also mean $15 \mathrm{ppm}$ for one yeat As such, the concept of a cumulative exposure inder based on ppm-months does not distinguish between concentration and duration of exposure. The second level of $720 \mathrm{pp}$-months is equivalent to an exposure of $2 \mathrm{ppm}$ for 30 years or $4 \mathrm{ppm}$ for 15 years. Needless to say, these exposure groupings were arbitrary, except that they would shed some light on the low level range Approximately $50 \%$ of the continuously exposed

Table 5 Distribution by year of first occupational exposure to benzene

\begin{tabular}{|c|c|c|}
\hline Year of first exposure to benzene & Frequency & $\%$ \\
\hline $\begin{array}{l}1908-34 \\
1935-39 \\
1940-44 \\
1945-49 \\
1950-54 \\
1955-59 \\
1960-64 \\
1965-69 \\
1970-74 \\
1975-77\end{array}$ & $\begin{array}{r}170 \\
153 \\
448 \\
953 \\
884 \\
466 \\
599 \\
543 \\
359 \\
27\end{array}$ & $\begin{array}{r}3.69 \\
3.32 \\
9 \cdot 73 \\
20 \cdot 71 \\
19 \cdot 21 \\
10 \cdot 13 \\
13.02 \\
11 \cdot 80 \\
7.80 \\
0.59\end{array}$ \\
\hline Total & 4602 & $100 \cdot 00$ \\
\hline
\end{tabular}


workers were exposed to less than $180 \mathrm{ppm}$-months, $30 \%$ to $180-719$ ppm-months, and $20 \%$ to more than $720 \mathrm{ppm}$-months. It should be pointed out that, because of the nature of the estimated historical industrial hygiene data, these exposure groups should be viewed on a relative, rather than on an absolute, basis.

Another method used to relate benzene exposure level to mortality was through the use of peak exposure rather than cumulative exposure of eight hour TWA. Since each exposed job (intermittent or continuous) was characterised by a peak exposure, the cohort members could be classified according to their maximum peak exposure through their entire exposure history. Table 2 shows the distribution of the exposed cohort by maximum peak exposure. More than half those exposed were exposed to a ceiling level of more than $100 \mathrm{ppm}$ at some time during their employment.

Table 3 shows the distribution of duration of exposure by exposure group. More than half the exposure cohort $(54.26 \%)$ were exposed for five years or more. On the other hand, 516 individuals were exposed for between six months and a year. The average duration of exposure was 10 years. Table 4 gives the distribution by age at first exposure. The majority $(56 \cdot 15 \%)$ was first exposed before age 30 and only one individual was first exposed after age 65 . The average age at first exposure was 30 . Finally, the distribution by year of first exposure is presented in table 5 . Slightly more than half $(56.66 \%)$ were exposed for the first time before 1955 . Thus, with regard to exposure to benzene, more than half the exposed cohort could have a latent period of at least 22 years.

\section{Results}

ANALYSIS BY DURATION OF EXPOSURE

Table 6 shows the observed numbers of deaths and

Table 6 Observed deaths by cause and SMRs for all cohort members exposed to benzene by duration of occupational exposure to benzene

\begin{tabular}{|c|c|c|c|c|c|c|}
\hline \multirow[b]{3}{*}{ Cause of death (8th ICDA) } & \multicolumn{6}{|c|}{ Duration of exposure } \\
\hline & \multicolumn{2}{|c|}{$<5$ years } & \multicolumn{2}{|c|}{$5-14$ years } & \multicolumn{2}{|c|}{$\geqslant 15$ years } \\
\hline & $O b s$ & $S M R$ & Obs & $S M R$ & Obs & $S M R$ \\
\hline All causes & 263 & $88 \cdot 6^{*}$ & 215 & $83 \cdot 2+$ & 232 & $87 \cdot 8^{*}$ \\
\hline All cancers $(140-209)$ : & 49 & 91.4 & 53 & $108 \cdot 8$ & 59 & $107 \cdot 2$ \\
\hline Cancer of buccal cavity and pharynx $(140-149)$ & 1 & $53 \cdot 8$ & 1 & $58 \cdot 4$ & 0 & 0 \\
\hline Cancer of digestive system $(150-159)$ : & 10 & $67 \cdot 1$ & 7 & $49 \cdot 8$ & 16 & $102 \cdot 0$ \\
\hline Cancer of oesophagus (150) & 2 & $119 \cdot 8$ & 0 & 0 & 2 & 118.4 \\
\hline Cancer of stomach (151) & 1 & $31 \cdot 4$ & 2 & $64 \cdot 6$ & 3 & $94 \cdot 3$ \\
\hline Cancer of large intestine (153) & 3 & $72 \cdot 3$ & 1 & $26 \cdot 3$ & 8 & $175 \cdot 1$ \\
\hline Cancer of liver $(155-156)$ & 1 & $90 \cdot 1$ & 0 & 0 & 0 & 0 \\
\hline Cancer of pancreas (157) & 2 & $69 \cdot 7$ & 4 & $148 \cdot 5$ & 2 & 63.9 \\
\hline Cancer of respiratory system $(160-163)$ : & $2 \overline{1}$ & $118 \cdot 6$ & 24 & $147 \cdot 9$ & 22 & 112.9 \\
\hline Cancer of lung (162-163) & 20 & $120 \cdot 2$ & 24 & $157 \cdot 5^{*}$ & 21 & $114 \cdot 3$ \\
\hline Cancer of bone $(170)$ & 0 & 0 & 1 & $373 \cdot 4$ & 1 & $398 \cdot 4$ \\
\hline Cancer of skin $(172-173)$ & 1 & $89 \cdot 3$ & 0 & 0 & 1 & $120 \cdot 6$ \\
\hline Cancer of prostate (185) & 1 & $39 \cdot 4$ & 4 & $152 \cdot 1$ & 2 & $57 \cdot 0$ \\
\hline Cancer of bladder (188) & 0 & 0 & 2 & $168 \cdot 7$ & 2 & $133 \cdot 0$ \\
\hline Cancer of kidney (189) & 2 & $153 \cdot 8$ & 1 & $85 \cdot 1$ & 1 & $74 \cdot 4$ \\
\hline Cancer of brain and CNS (191-192) & 1 & $40 \cdot 5$ & 3 & $181 \cdot 8$ & 2 & 133.4 \\
\hline Lymphatic \& haematopoietic cancer $(200-209)$ : & 7 & $118 \cdot 0$ & 8 & $163 \cdot 1$ & 4 & $82 \cdot 6$ \\
\hline Lymphosarcoma and reticulosarcoma (200) & 1 & $76 \cdot 3$ & 1 & $89 \cdot 2$ & 2 & $179 \cdot 5$ \\
\hline Hodgkin`s disease (201) & 1 & $92 \cdot 6$ & 1 & $130 \cdot 1$ & 0 & 0 \\
\hline Leukaemia \& aleukaemia (204-207) & 2 & $88 \cdot 5$ & 4 & $215 \cdot 8$ & 1 & $54 \cdot 0$ \\
\hline Other lymphatic tissue cancer $(202,203,208)$ & 3 & 241.9 & 2 & $177 \cdot 8$ & $i$ & 76.9 \\
\hline Benign neoplasms $(210-239)$ & 1 & $108 \cdot 7$ & 2 & $258 \cdot 3$ & 0 & 0 \\
\hline Diabetes mellitus (250) & 4 & 96.4 & 2 & $54 \cdot 1$ & 3 & $76 \cdot 8$ \\
\hline Diseases of blood $(280-289)$ & 1 & $144 \cdot 9$ & 0 & 0 & 0 & 0 \\
\hline Diseases of circulatory system $(390-458)$ : & 120 & 89.9 & 106 & $84 \cdot 9$ & 132 & 94.9 \\
\hline Arteriosclerotic heart disease $(410-413)$ & 83 & $92 \cdot 9$ & 68 & $81 \cdot 8$ & 95 & 97.9 \\
\hline Vascular lesions of CNS $(430-438)$ & 14 & $77 \cdot 3$ & 13 & $74 \cdot 5$ & 15 & $79 \cdot 0$ \\
\hline Non-malignant respiratory disease $(460-519)$ : & 9 & $60 \cdot 7$ & 11 & $81 \cdot 2$ & 8 & $52 \cdot 5$ \\
\hline Pneumonia $(480-486)$ & 4 & $63 \cdot 2$ & 5 & $37 \cdot 8$ & 3 & $53 \cdot 5$ \\
\hline Emphysema (492) & 3 & $98 \cdot 0$ & 5 & $170 \cdot 1$ & 4 & 98.6 \\
\hline Diseases of digestive system $(520-577)$ : & 9 & $54 \cdot 5$ & 6 & $42 \cdot 4^{*}$ & 2 & $14 \cdot 9+$ \\
\hline Cirrhosis of liver (551) & 6 & 65.4 & 3 & $38 \cdot 9$ & 1 & $13 \cdot 6^{*}$ \\
\hline Diseases of genitourinary system (580-629) & 2 & $39 \cdot 0$ & 1 & $21 \cdot 7$ & 3 & $77 \cdot 4$ \\
\hline Accidents, poisonings, \& violence (E800-E998) & $5 \overline{4}$ & $112 \cdot 0$ & 27 & $85 \cdot 6$ & 21 & $105 \cdot 7$ \\
\hline Accidents $(800-949)$ & 40 & 123.9 & 18 & $85 \cdot 9$ & 12 & $92 \cdot 3$ \\
\hline Motor vehicle accidents (810-827) & 20 & $125 \cdot 5$ & 12 & $126 \cdot 1$ & 9 & $165 \cdot 7$ \\
\hline Suicide $(950-959)$ & 5 & $55 \cdot 0$ & 1 & $15 \cdot 4^{*}$ & 7 & $149 \cdot 4$ \\
\hline
\end{tabular}

* Significant at 0.05.

†Significant at $0 \cdot 01$. 
Table 7 Observed deaths by cause and SMRs for continuously exposed cohort members by duration of continuous exposure to benzene

\begin{tabular}{|c|c|c|c|c|c|c|c|}
\hline \multirow[b]{3}{*}{ Cause of death (8th ICDA) } & \multicolumn{6}{|c|}{ Duration of exposure } & $\stackrel{\vec{\omega}}{\rightarrow}$ \\
\hline & \multicolumn{2}{|c|}{$<5$ years } & \multicolumn{2}{|c|}{$5-14$ years } & \multicolumn{2}{|c|}{$\geqslant 15$ years } & 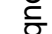 \\
\hline & $\overline{O b s}$ & $S M R$ & $\overline{O b s}$ & $S M R$ & $\overline{O b s}$ & $S M R$ & 0 \\
\hline All causes & 311 & $87 \cdot 6$ & 128 & 86.0 & 92 & $84 \cdot 1$ & 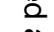 \\
\hline All cancers (140-209): & 66 & $99 \cdot 4$ & 39 & $136 \cdot 3$ & 18 & 79.4 & 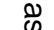 \\
\hline Cancer of buccal cavity and pharynx (140-149) & 1 & $42 \cdot 4$ & 1 & $101 \cdot 4$ & 0 & 0 & \\
\hline Cancer of digestive system $(150-159)$ : & 14 & $75 \cdot 1$ & 7 & $85 \cdot 1$ & 5 & $78 \cdot 0$ & $\overrightarrow{0}$ \\
\hline Cancer of oesophagus (150) & 3 & 140.9 & 0 & 0 & 1 & $140 \cdot 6$ & 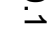 \\
\hline Cancer of stomach (15i) & 2 & $50 \cdot 8$ & 2 & $110 \cdot 9$ & 1 & $76 \cdot 1$ & \\
\hline Cancer of large intestine (153) & 6 & 115.6 & 1 & $44 \cdot 7$ & 3 & $162 \cdot 3$ & S \\
\hline Cancer of liver $(155-156)$ & 1 & $73 \cdot 5$ & 0 & 0 & 0 & 0 & 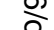 \\
\hline Cancer of pancreas (157) & $i$ & $27 \cdot 6$ & 3 & $189 \cdot 1$ & 0 & 0 & రి \\
\hline Cancer of respiratory system $(160-163)$ : & 27 & $120 \cdot 0$ & 18 & $187 \cdot 2^{*}$ & 4 & $50 \cdot 1$ & $\frac{6}{3}$ \\
\hline Cancer of lung (162-163) & 26 & 122.9 & 18 & $199 \cdot 1^{*}$ & 3 & $39 \cdot 8$ & \\
\hline Cancer of bone (170) & 1 & $263 \cdot 2$ & 1 & $662 \cdot 6$ & 0 & 0 & $\vec{A}$ \\
\hline Cancer of skin $(172-173)$ & 1 & $78 \cdot 7$ & 0 & 0 & 0 & 0 & के \\
\hline Cancer of prostate (185) & 4 & $122 \cdot 3$ & 2 & $119 \cdot 7$ & 0 & 0 & $\omega$ \\
\hline Cancer of bladder (188) & 1 & $64 \cdot 5$ & 0 & 0 & 2 & $334 \cdot 1$ & $\infty$ \\
\hline Cancer of kidney (189) & 3 & $184 \cdot 1$ & 0 & 0 & 1 & $182 \cdot 7$ & N \\
\hline Cancer of brain and CNS (191-192) & 2 & $85 \cdot 1$ & 3 & $324 \cdot 4$ & 1 & $159 \cdot 9$ & 윽 \\
\hline Lymphatic \& haematopoietic cancer $(200-209)$ : & 7 & $101 \cdot 3$ & 6 & $213 \cdot 3$ & 2 & $99 \cdot 3$ & \\
\hline Lymphosarcoma and reticulosarcoma (200) & 1 & 64.5 & 1 & $156 \cdot 2$ & 1 & 217.8 & \\
\hline Hodgkin's disease (201) & 1 & 87.7 & 1 & $237 \cdot 4$ & 0 & 0 & $=$ \\
\hline Leukaemia \& aleukaemia (204-207) & 2 & $76 \cdot 3$ & 3 & $283 \cdot 5$ & 1 & $131 \cdot 2$ & \\
\hline Other lym phatic tissue cancer $(202,203,208)$ & 3 & 193.6 & 1 & $149 \cdot 1$ & 0 & 0 & $\overline{\widetilde{\alpha}}$ \\
\hline Benign neopla sms $(210-239)$ & 2 & $185 \cdot 2$ & 1 & $234 \cdot 7$ & 0 & 0 & t \\
\hline Diabetes mell fus (250) & 5 & 99.8 & 1 & $46 \cdot 3$ & 2 & $122 \cdot 4$ & $\infty$ \\
\hline Diseases of b ood $(280-289)$ & 1 & $123 \cdot 5$ & 0 & 0 & 0 & 0 & $\mathbf{v}$ \\
\hline Diseases of circulatory system $(390-458)$ : & 146 & 87.9 & 62 & $85 \cdot 5$ & 61 & $107 \cdot 4$ & \\
\hline Arteriosclerotic heart disease $(410-413)$ & 98 & $87 \cdot 3$ & 41 & 84.8 & 50 & 127.4 & \\
\hline Vascular lesions of CNS $(430-438)$ & 17 & 75.8 & 7 & $67 \cdot 7$ & 7 & $87 \cdot 7$ & $\sum^{0}$ \\
\hline Non-malignant respiratory disease $(460-519)$ : & 15 & $82 \cdot 2$ & 5 & $63 \cdot 2$ & 1 & $16 \cdot 0^{*}$ & $<$ \\
\hline Pneumonia (480-486) & 4 & $52 \cdot 4$ & 3 & 91.9 & 1 & $42 \cdot 2$ & $\overline{0}$ \\
\hline Emphysema (492) & 8 & $202 \cdot 5$ & 2 & $113 \cdot 1$ & 0 & 0 & صి \\
\hline Diseases of digestive system $(520-577)$ : & 9 & $45 \cdot 5$ & 2 & $25 \cdot 1^{*}$ & 1 & $17 \cdot 8^{*}$ & $\frac{2}{1}$ \\
\hline Cirrhosis of liver (551) & 7 & $63 \cdot 2$ & 1 & 22.9 & 0 & 0 & ○ \\
\hline Diseases of genitourinary system $(580-629)$ & $i$ & $16.8^{*}$ & 1 & $38 \cdot 0$ & 1 & $60 \cdot 7$ & 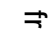 \\
\hline Accidents, poisonings, \& violence (E800-E998) & 55 & 111.4 & 12 & $69 \cdot 2$ & 6 & $67 \cdot 7$ & $\subseteq$ \\
\hline Accidents $(800-949)$ & 37 & $112 \cdot 8$ & 6 & $52 \cdot \overline{3}$ & 4 & $69 \cdot 2$ & 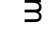 \\
\hline Motor vehicle accidents (810-827) & 21 & $134 \cdot 8$ & 3 & $57 \cdot 3$ & 3 & $122 \cdot 4$ & 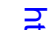 \\
\hline Suicide $(950-959)$ & 7 & 72.6 & 1 & 27.8 & 1 & $49 \cdot 0$ & 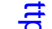 \\
\hline
\end{tabular}

SMRs among the chemical workers exposed to benzene (continuous and intermittent) by duration of benzene exposure. No obvious increasing trend by duration of exposure was identified for any cause of death examined, except, perhaps, for stomach cancer and lymphosarcoma and reticulosarcoma. In each case, however, the number of deaths was small. No increasing trend was noted for either all lymphatic and haematopoietic cancer, leukaemia, or other lymphatic tissue cancer.

Those exposed to benzene for 5-14 years experienced an increased risk in lung cancer (table 6). The SMR was 157.5 (24 observed), statistically significant at the 0.05 level. Nevertheless, no trend by duration of employment for lung cancer was detected.

A similar analysis by duration of continuous exposure for the continuously exposed group was carried out, and the results are presented in table 7. A trend was found for lymphosarcoma and reticulo- sarcoma by duration of continuous exposure although the number of deaths was small.

\section{ANALYSIS BY LATENCY}

Long latent periods are usually required for chroniẹ diseases to develop and it is often more appropriate to examine mortality experience only after a certain lag. period has elapsed. Table 8 presents the observed deaths by cause and SMRs for all cohort members exposed to benzene (intermittent and continuous) bæ latency since first exposure. A slightly increasing trend $\omega$ by latency was detected for all cancers, lung cancer brain cancer, leukaemia, and arteriosclerotic heare disease. Table 8 also indicates that the SMR for othe lymphatic tissue cancer among those with 10 to $19^{2}$ years of latency was 455.6 (4 observed), statistically significant. In the same latency group mortality from motor vehicle accidents was also statistically significant $(18$ observed, $\mathrm{SMR}=175 \cdot 2)$. 
Table 8 Observed deaths by cause and SMRs for all cohort members exposed to benzene (intermittent and continuous exposure) by latency since first exposure

\begin{tabular}{|c|c|c|c|c|c|c|}
\hline \multirow[b]{3}{*}{ Cause of death (8th ICDA) } & \multicolumn{6}{|c|}{ Latency since first exposure } \\
\hline & \multicolumn{2}{|c|}{$<10$ years } & \multicolumn{2}{|c|}{$10-19$ years } & \multicolumn{2}{|c|}{$\geqslant 20$ years } \\
\hline & $\overline{O b s}$ & $S M R$ & $\overline{O b s}$ & $S M R$ & Obs & $S M R$ \\
\hline All causes & 90 & $68 \cdot 0 \dagger$ & 201 & $87 \cdot 2$ & 419 & $91 \cdot 8$ \\
\hline All cancers $(140-209)$ : & 16 & $82 \cdot 8$ & 41 & $101 \cdot 1$ & 104 & $106 \cdot 7$ \\
\hline Cancer of buccal cavity and pharynx $(140-149)$ & 0 & 0 & 1 & $67 \cdot 6$ & 1 & 29.9 \\
\hline Cancer of digestive system $(150-159)$ : & 4 & $74 \cdot 4$ & 8 & $68 \cdot 2$ & 21 & $76 \cdot 2$ \\
\hline Cancer of oesophagus (150) & 1 & $212 \cdot 6$ & 1 & $79 \cdot 2$ & 2 & $61 \cdot 7$ \\
\hline Cancer of stomach (151) & 0 & 0 & 2 & $75 \cdot 0$ & 4 & $72 \cdot 9$ \\
\hline Cancer of large intestine (153) & 1 & $69 \cdot 5$ & 2 & $64 \cdot 9$ & 9 & $112 \cdot 4$ \\
\hline Cancer of liver $(155-156)$ & 0 & 0 & 0 & 0 & 1 & $53 \cdot 2$ \\
\hline Cancer of pancreas (157) & 2 & $215 \cdot 4$ & 2 & $90 \cdot 0$ & 4 & $72 \cdot \overline{2}$ \\
\hline Cancer of respiratory system $(160-163)$ : & 4 & $76 \cdot 0$ & 17 & $129 \cdot 7$ & 46 & $131 \cdot 3$ \\
\hline Cancer of lung (162-163) & 4 & $81 \cdot 6$ & 16 & $130 \cdot 4$ & 45 & $136 \cdot 0$ \\
\hline Cancer of bone $(170)$ & 0 & 0 & 2 & $397 \cdot 2$ & 1 & 243.9 \\
\hline Cancer of skin $(172-173)$ & 1 & $177 \cdot 0$ & 0 & 0 & 1 & $74 \cdot 6$ \\
\hline Cancer of prostate (185) & 4 & 0 & 0 & 0 & 7 & $104 \cdot 3$ \\
\hline Cancer of bladder (188) & 0 & 0 & 0 & 0 & 4 & $151 \cdot 5$ \\
\hline Cancer of kidney (189) & 0 & 0 & 3 & $286 \cdot 9$ & 1 & $43 \cdot 5$ \\
\hline Cancer of brain and CNS (191-192) & 1 & $94 \cdot 4$ & 2 & $118 \cdot 4$ & 3 & $124 \cdot 0$ \\
\hline Lymphatic \& haematopoietic cancer (200-209): & 3 & $102 \cdot 3$ & 8 & $175 \cdot 9$ & 8 & 97.6 \\
\hline Lymphosarcoma and reticulosarcoma (200) & 1 & $161 \cdot 3$ & 1 & 89.4 & 2 & $110 \cdot 5$ \\
\hline Hodgkin's disease $(201)$ & 1 & 130.5 & 1 & $121 \cdot 1$ & 0 & 0 \\
\hline Leukaemia \& aleukaemia (204-207) & 1 & $87 \cdot 5$ & 2 & 116.9 & 4 & $128 \cdot 6$ \\
\hline Other lymphatic tissue cancer $(202,203,208)$ & 0 & 0 & 4 & $455 \cdot 6^{*}$ & 2 & 83.7 \\
\hline Benign neoplasms $(210-239)$ & 0 & 0 & 2 & $268 \cdot 7$ & 1 & $91 \cdot 7$ \\
\hline Diabetes mellitus (250) & 1 & $59 \cdot 9$ & 1 & $32 \cdot 0$ & 7 & $100 \cdot 6$ \\
\hline Diseases of blood $(280-289)$ & 0 & 0 & 0 & 0 & 1 & $108 \cdot 7$ \\
\hline Diseases of circulatory system $(390-458)$ : & 31 & $63 \cdot 0 \dagger$ & 93 & $86 \cdot 5$ & 234 & $97 \cdot 3$ \\
\hline Arteriosclerotic heart disease $(410-413)$ & 19 & $62 \cdot 0^{*}$ & 65 & $91 \cdot 0$ & 162 & $96 \cdot 8$ \\
\hline Vascular lesions of CNS $(430-438)$ & 2 & $31 \cdot 4$ & 11 & $78 \cdot 8$ & 29 & $84 \cdot 8$ \\
\hline Non-malignant respiratory disease $(460-519)$ : & 5 & $89 \cdot 2$ & 6 & $54 \cdot 4$ & 17 & 63.0 \\
\hline Pneumonia $(480-486)$ & 4 & $147 \cdot 8$ & 3 & $61 \cdot 1$ & 5 & $50 \cdot 0$ \\
\hline Emphysema (492) & 0 & 0 & 3 & $134 \cdot 5$ & 9 & $127 \cdot 1$ \\
\hline Diseases of digestive system $(520-577)$ : & 1 & $13 \cdot 5+$ & 6 & $42 \cdot 7^{*}$ & 10 & $44 \cdot 2 *$ \\
\hline Cirrhosis of liver (551) & 1 & $26 \cdot 3$ & 3 & $37 \cdot 7$ & 6 & $48 \cdot 0$ \\
\hline Diseases of genitourinary system (580-629) & $i$ & $35 \cdot 0$ & 1 & $24 \cdot 7$ & 4 & $59 \cdot 6$ \\
\hline Accidents, poisonings, \& violence (E800-E998) & 33 & $96 \cdot 8$ & 39 & $114 \cdot 2$ & 30 & $95 \cdot 7$ \\
\hline Accidents (800-949) & 23 & $97 \cdot 7$ & 29 & $129 \cdot 7$ & 18 & $88 \cdot 5$ \\
\hline Motor vehicle accidents $(810-827)$ & 14 & $113 \cdot 2$ & 18 & $175 \cdot 2^{*}$ & 9 & $109 \cdot 2$ \\
\hline Suicide $(950-959)$ & 3 & 50.4 & 3 & $40 \cdot 8$ & 7 & $100 \cdot 3$ \\
\hline
\end{tabular}

*Significant at $0 \cdot 05$.

+Significant at 0.01 .

Table 9 presents the results of a similar analysis by latency for the continously exposed group. An upward trend by latency was noted for brain cancer, leukaemia, diabetes mellitus, and arteriosclerotic heart disease.

\section{ANALYSIS BY CUMULATIVE EXPOSURE}

As stated earlier, for each job that was classified as continuously exposed, an eight hour time weighted average benzene exposure level (ppm) was estimated. For all cohort members in the continuous exposure group, a cumulative exposure index in terms of ppmmonths was computed, and each of their person-years under observation was associated with a particular cumulative index (ppm-months) as well. These person-years were grouped in the appropriate cumulative exposure category in calculating SMRs.

Table 10 shows the analysis by cumulative exposure. The three cumulative exposure categories ( $<180,180-719, \geqslant 720$ ppm-months) discussed earlier were used in the analysis. Since comparing indirectly adjusted SMRs (even though all based on the same standard population) among different cumulative exposure groups might not be appropriate if the underlying age distributions differed, the latter were examined. There were slightly larger proportions of person-years in the younger age groups in the nonexposed than in the heavily exposed group. The overall distributions, however, were not dissimilar, and a comparison based on SMRs would not be inappropriate.

It is noted from table 10 that those with a cumulative exposure of 180-719 ppm-months experienced a statistically significant increased risk of lung cancer (19 observed, SMR $=173.7$ ), and those with $<180 \mathrm{ppm}$-months were at a significantly raised risk 
Table 9 Observed deaths by cause and SMRs for continuously exposed cohort members by latency since first occupation exposure

\begin{tabular}{|c|c|c|c|c|c|c|c|}
\hline \multirow[b]{3}{*}{ Cause of death (8th ICDA) } & \multicolumn{6}{|c|}{ Latency since first exposure } & $\stackrel{\infty}{\longrightarrow}$ \\
\hline & \multicolumn{2}{|c|}{$<10$ years } & \multicolumn{2}{|c|}{$10-19$ years } & \multicolumn{2}{|c|}{$\geqslant 20$ years } & $\overline{\bar{\sigma}}$ \\
\hline & $\overline{O b s}$ & $S M R$ & $\overline{O b s}$ & $S M R$ & $\overline{O b s}$ & $S M R$ & $\frac{0}{9}$ \\
\hline All causes & 76 & $68 \cdot 6$ & 170 & $93 \cdot 1$ & 285 & $89 \cdot 1$ & \\
\hline All cancers $(140-209)$ : & 14 & $86 \cdot 2$ & 41 & 126.5 & 68 & 98.5 & 0 \\
\hline Cancer of buccal cavity and pharynx (140-149) & 0 & 0 & 1 & $84 \cdot 3$ & 1 & $42 \cdot 0$ & 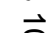 \\
\hline Cancer of digestive system $(150-159)$ : & 5 & 107.9 & 5 & $53 \cdot 0$ & 16 & $83 \cdot 3$ & s. \\
\hline Cancer of oesophagus (150) & 1 & 223.7 & 1 & 91.8 & 2 & 88.5 & - \\
\hline Cancer of stomach (151) & $\mathrm{i}$ & 85.9 & 1 & $46 \cdot 2$ & 3 & 80.4 & \\
\hline Cancer of large intestine (153) & 2 & $168 \cdot 8$ & 1 & $41 \cdot 2$ & 7 & 123.9 & 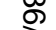 \\
\hline Cancer of liver (155-156) & 0 & 0 & 0 & 0 & 1 & 78.1 & c \\
\hline Cancer of pancreas (157) & 1 & $126 \cdot 0$ & 1 & $56 \cdot 0$ & 2 & $51 \cdot 2$ & \\
\hline Cancer of respiratory system $(160-163)$ : & 4 & 89.9 & 18 & $171 \cdot 2^{*}$ & 27 & $107 \cdot 4$ & \\
\hline Cancer of lung $(162-163)$ & 4 & $96 \cdot 6$ & 16 & 162.6 & 27 & 113.6 & \\
\hline Cancer of bone $(170)$ & 0 & 0 & 1 & $513 \cdot 3$ & 1 & $357 \cdot 1$ & \\
\hline Cancer of skin $(172-173)$ & 1 & $219 \cdot 9$ & 0 & 0 & 0 & 0 & \\
\hline Cancer of prostate (185) & 0 & 0 & 2 & $150 \cdot 4$ & 4 & $86 \cdot 2$ & \\
\hline Cancer of bladder (188) & 0 & 0 & 0 & 0 & 3 & 163.9 & \\
\hline Cancer of kidney (189) & 0 & 0 & 3 & $368 \cdot 4$ & 1 & $60 \cdot 6$ & \\
\hline Cancer of brain and CNS (191-192) & 1 & 117.9 & 2 & $155 \cdot 5$ & 3 & $170 \cdot 5$ & \\
\hline Lymphatic \& haematopoietic cancer $(200-209)$ : & 2 & 84.8 & 7 & 198.2 & 6 & $102 \cdot 7$ & \\
\hline Lymphosarcoma and reticulosarcoma (200) & 1 & 199.7 & $i$ & 115.8 & 1 & 77.5 & \\
\hline Hodg kin's disease (201) & $i$ & 166.6 & $i$ & 159.8 & 0 & 0 & $\cong$ \\
\hline Leuk:1emia \& aleukaemia (204-207) & 0 & 0 & 2 & $151 \cdot 3$ & 4 & 181.8 & \\
\hline Othe : lymphatic tissue cancer $(202,203,208)$ & 0 & 0 & 3 & $423 \cdot 3$ & 1 & 58.5 & \\
\hline Benign n :oplasms $(210-239)$ & 0 & 0 & 2 & $347 \cdot 1$ & $\mathrm{i}$ & 129.9 & \\
\hline Diabetes mellitus (250) & 1 & $71 \cdot 2$ & 2 & $79 \cdot 2$ & 5 & 102.7 & \\
\hline Diseases of blood (280-289) & 0 & 0 & 0 & 0 & 1 & $156 \cdot 3$ & \\
\hline Diseases of circulatory system $(390-458)$ : & 27 & $64 \cdot 0^{*}$ & 75 & $87 \cdot 5$ & 167 & 99.7 & \\
\hline Arteriosclerotic heart disease $(410-413)$ & 16 & 62.9 & 55 & 97.7 & 118 & 99.9 & \\
\hline Vascular lesions of CNS $(430-438)$ & 3 & $51 \cdot 4$ & 7 & $60 \cdot 1$ & 21 & 90.4 & 5 \\
\hline Non-malignant respiratory disease $(460-519)$ : & 4 & 83.6 & 7 & $79 \cdot 4$ & 10 & $53 \cdot 1$ & \\
\hline Pneumonia $(480-486)$ & 3 & $126 \cdot 4$ & 2 & 50.1 & 3 & $43 \cdot 4$ & 0 \\
\hline Emphysema (492) & 0 & 0 & 4 & $227 \cdot 2$ & 6 & 120.0 & \\
\hline Diseases of digestive system (520-577): & 2 & $32 \cdot 1$ & 6 & $54 \cdot 5$ & 4 & $24.9+$ & ลุ \\
\hline Cirrhosis of liver (551) & 1 & $31 \cdot 0$ & 4 & $64 \cdot 1$ & 3 & $33.0^{*}$ & \\
\hline Diseases of genitourinary system $(580-629)$ & $\mathrm{i}$ & $40 \cdot 3$ & 0 & 0 & 2 & 44.5 & $z$ \\
\hline Accidents, poisonings, \& violence (E800-E998) & 26 & 95.8 & 27 & $103 \cdot 6$ & 20 & $89 \cdot 3$ & \\
\hline Accidents $(800-949)$ & 18 & 97.0 & 17 & 99.6 & 12 & $83 \cdot 1$ & \\
\hline Motor vehicle accidents $(810-827)$ & 12 & $125 \cdot 0$ & 9 & 115.5 & 6 & 102.0 & 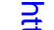 \\
\hline Suicide $(950-959)$ & 2 & $42 \cdot 8$ & 2 & $36 \cdot 2$ & 5 & 98.2 & $\tau$ \\
\hline
\end{tabular}

of motor vehicle accidents $(20$ observed, SMR $=177 \cdot 7$ ). No increasing trend by cumulative exposure to benzene, however, was detected for either cause of death.

In fact, based on SMRs, no increasing trend by cumulative exposure was found for any cause of death examined except for lymphatic and haematopoietic cancer, lymphosarcoma and reticulosarcoma, and, perhaps, leukaemia. For convenience, the observed deaths, expected deaths, SMRs, and their 95\% confidence limits for all lymphopoietic cancer, leukaemia, non-Hodgkin's lymphoma, and nonHodgkin's lymphopoietic cancer by cumulative exposure to benzene are presented in table 11. The rationale for these groupings of causes of death is given in part $\mathrm{I} .{ }^{1}$ As a baseline for comparison, the occupationally non-exposed group is also included in the table. Based on table 11, there was clearly a monotonic increasing trend of lymphopoietic cancer SMR by cumulative exposure. The SMRs, in increasi鮑 cumulative exposure order, were $34 \cdot 6,91 \cdot 3,146 \cdot 8$, and 175.2. The increase did not appear to be linear but rose more steeply in the low exposure range and became flatter at the high exposure levels.

The dose-response relation for leukaemia was nt strictly monotonic; the SMR rose from 0 to $96 \%$; dropped slightly to 78.2 and rose back to $275 \cdot 8$. T number of deaths from leukaemia in each of the cumulative exposure groups was small, and the assops ated statistical variability was large.

For non-Hodgkin's lymphoma (lymphosarcoma, reticulosarcoma, and other lymphatic tissue cancé, the SMRs rose from 50.8 in the comparison grouf, through 116.7 in the $<180 \mathrm{ppm}$-months group to 186.3 in the $180-719 \mathrm{ppm}$-months group, and dropped to 74.6 in the $>720 \mathrm{ppm}$-months group. $\frac{\mathrm{D}}{\mathbb{D}}$

The SMRs for non-Hodgkin's lymphopoietic ca\& cer increased with cumulative exposure to benzere; 
Table 10 Observed deaths by cause and SMRs for all cohort members continuously exposed to benzene by cumulative exposure

\begin{tabular}{|c|c|c|c|c|c|c|}
\hline \multirow[b]{3}{*}{ Cause of death (8th ICDA) } & \multicolumn{6}{|c|}{ Cumulative exposure (ppm-months) } \\
\hline & \multicolumn{2}{|c|}{$<180$} & \multicolumn{2}{|c|}{$180-719$} & \multicolumn{2}{|c|}{$\geqslant 720$} \\
\hline & $\overline{O b s}$ & $S M R$ & Obs & $S M R$ & Obs & $S M R$ \\
\hline All causes & 259 & $90 \cdot 5$ & 181 & $98 \cdot 6$ & 91 & $63 \cdot 5+$ \\
\hline All cancers $(140-209)$ : & 56 & $102 \cdot 5$ & 45 & $129 \cdot 4$ & 22 & 77.8 \\
\hline Cancer of buccal cavity and pharynx (140-149) & 1 & $51 \cdot 7$ & 1 & 83.0 & 0 & 0 \\
\hline Cancer of digestive system $(150-159)$ : & 12 & $77 \cdot 9$ & 9 & $89 \cdot 7$ & 5 & $63 \cdot 9$ \\
\hline Cancer of oesophagus (150) & 3 & $166 \cdot 4$ & 1 & $82 \cdot 6$ & 0 & 0 \\
\hline Cancer of stomach (15i) & 2 & $61 \cdot 5$ & 2 & $89 \cdot 3$ & 1 & $63 \cdot 9$ \\
\hline Cancer of large intestine (153) & 5 & 117.0 & 2 & 74.8 & 3 & $129 \cdot 4$ \\
\hline Cancer of liver $(155-156)$ & 0 & 0 & 1 & $133 \cdot 3$ & 0 & 0 \\
\hline Cancer of pancreas (157) & 2 & $66 \cdot 6$ & $i$ & $52 \cdot 1$ & 1 & $63 \cdot 8$ \\
\hline Cancer of respiratory system $(160-163)$ : & 23 & $123 \cdot 3$ & 19 & $163 \cdot 3$ & 7 & $71 \cdot 3$ \\
\hline Cancer of lung (162-163) & 22 & 125.4 & 19 & $173 \cdot 7^{*}$ & 6 & 64.8 \\
\hline Cancer of bone (170) & 0 & 0 & 1 & $531 \cdot 8$ & 1 & $678 \cdot 1$ \\
\hline Cancer of skin $(172-173)$ & 1 & $100 \cdot 8$ & 0 & 0 & 0 & 0 \\
\hline Cancer of prostate (185) & 2 & $69 \cdot 1$ & 4 & $193 \cdot 2$ & 0 & 0 \\
\hline Cancer of bladder (188) & 2 & $153 \cdot 2$ & 0 & 0 & 1 & $139 \cdot 3$ \\
\hline Cancer of kidney (189) & 2 & 151.0 & 2 & $245 \cdot 0$ & 0 & 0 \\
\hline Cancer of brain and CNS (191-192) & 3 & $164 \cdot 3$ & 2 & $180 \cdot 6$ & 1 & $103 \cdot 5$ \\
\hline Lymphatic \& haematopoietic cancer (200-209): & 5 & $91 \cdot 3$ & 5 & 146.8 & 5 & $175 \cdot 2$ \\
\hline Lymphosarcoma and reticulosarcoma (200) & 1 & $81 \cdot 2$ & 1 & 131.6 & 1 & 151.0 \\
\hline Hodgkin's disease (201) & 0 & 0 & $i$ & 191.6 & 1 & 240.5 \\
\hline Leukaemia \& aleukaemia (204-207) & 2 & $96 \cdot 8$ & $\mathrm{i}$ & $78 \cdot 2$ & 3 & 275.8 \\
\hline Other lymphatic tissue cancer $(202,203,208)$ & 2 & 155.4 & 2 & 244.9 & 0 & 0 \\
\hline Benign neoplasms $(210-239)$ & 2 & $239 \cdot 1$ & 1 & 188.9 & 0 & 0 \\
\hline Diabetes mellitus (250) & 5 & $121 \cdot 7$ & 2 & $75 \cdot 4$ & 1 & $49 \cdot 0$ \\
\hline Diseases of blood $(280-289)$ & 1 & 156.4 & 0 & 0 & 0 & 0 \\
\hline Diseases of circulatory system $(390-458)$ : & 115 & $84 \cdot 3$ & 94 & $106 \cdot 8$ & 60 & $84 \cdot 6$ \\
\hline Arteriosclerotic heart disease $(410-413)$ & 77 & $83 \cdot 5$ & 65 & 112.9 & 47 & 93.8 \\
\hline Vascular lesions of CNS (430-438) & 12 & $63 \cdot 9$ & 14 & $108 \cdot 0$ & 5 & $55 \cdot 6$ \\
\hline Non-malignant respiratory disease $(460-519)$ : & 14 & $93 \cdot 2$ & 6 & $62 \cdot 1$ & 1 & $12.9+$ \\
\hline Pneumonia $(480-486)$ & 4 & $64 \cdot 3$ & 4 & $96 \cdot 7$ & 0 & 0 \\
\hline Emphysema (492) & 7 & $210 \cdot 8$ & 2 & $98 \cdot 1$ & 1 & $50 \cdot 4$ \\
\hline Diseases of digestive system $(520-577)$ : & 10 & 63.4 & 1 & $10 \cdot 2+$ & $i$ & $12 \cdot 8+$ \\
\hline Cirrhosis of liver (551) & 7 & $79 \cdot 2$ & 1 & 18.7 & 0 & 0 \\
\hline Diseases of genitourinary system $(580-629)$ & 1 & $21 \cdot 0$ & 2 & $58 \cdot 8$ & 0 & 0 \\
\hline Accidents, poisonings, \& violence (E800-E998) & 48 & $130 \cdot 8$ & 22 & $96 \cdot 4$ & 3 & $18 \cdot 7 \dagger$ \\
\hline Accidents $(800-949)$ & 31 & $128 \cdot 2$ & 14 & $92 \cdot 5$ & 2 & $18 \cdot 6 \dagger$ \\
\hline Motor vehicle accidents $(810-827)$ & 20 & $177 \cdot 7^{*}$ & 6 & 85.0 & 1 & $20 \cdot 2$ \\
\hline Suicide $(950-959)$ & 4 & $55 \cdot 4$ & 4 & $90 \cdot 9$ & $i$ & $27 \cdot \overline{4}$ \\
\hline
\end{tabular}

*Significant at 0.05

†Significant at $0 \cdot 01$.

Table 11 Observed deaths, expected deaths, SMRs, and 95\% confidence intervals for lymphatic and haematopoietic cancer, leukaemia, non-Hodgkin's lymphoma, and non-Hodgkin's lymphopoietic cancer by cumulative occupational exposure to benzene

\begin{tabular}{|c|c|c|c|c|c|}
\hline Cause of death (8th ICD) & Variable & Non-exposed & $\begin{array}{l}<180 \\
\text { ppm-months }\end{array}$ & $\begin{array}{l}180-719 \\
\text { ppm-months }\end{array}$ & $\begin{array}{l}\geqslant 720 \\
\text { ppm-months }\end{array}$ \\
\hline $\begin{array}{l}\text { Lymphatic and haematopoietic } \\
\text { cancer }(200-209)\end{array}$ & $\begin{array}{l}\text { Obs } \\
\text { Exp } \\
\text { SMR } \\
95 \% \text { CI }\end{array}$ & $\begin{array}{l}3 \\
8 \cdot 68 \\
34 \cdot 6 \\
7 \cdot 1-101 \cdot 1\end{array}$ & $\begin{array}{l}5 \\
5 \cdot 48 \\
91 \cdot 3 \\
29 \cdot 5-213 \cdot 3\end{array}$ & $\begin{array}{l}5 \\
3 \cdot 41 \\
146 \cdot 8 \\
47 \cdot 5-343 \cdot 0\end{array}$ & $\begin{array}{l}5 \\
2 \cdot 85 \\
175 \cdot 2 \\
56 \cdot 7-409 \cdot 3\end{array}$ \\
\hline $\begin{array}{l}\text { Leukaemia and aleukaemia } \\
(204-207)\end{array}$ & $\begin{array}{l}\text { Obs } \\
\text { Exp } \\
\text { SMR } \\
95 \% \text { CI }\end{array}$ & $\begin{array}{l}0 \\
3 \cdot 40 \\
-\quad\end{array}$ & $\begin{array}{l}2 \\
2 \cdot 07 \\
96 \cdot 8 \\
11 \cdot 7-349 \cdot 4\end{array}$ & $\begin{array}{l}1 \\
1 \cdot 28 \\
78 \cdot 2 \\
2 \cdot 0-434 \cdot 4\end{array}$ & $\begin{array}{l}3 \\
1.09 \\
275 \cdot 8 \\
56 \cdot 9-806 \cdot 4\end{array}$ \\
\hline $\begin{array}{l}\text { Non-Hodgkin's lymphoma } \\
(200.202,203)\end{array}$ & $\begin{array}{l}\text { Obs } \\
\text { Exp } \\
\text { SMR } \\
95 \% \text { CI }\end{array}$ & $\begin{array}{l}2 \\
3 \cdot 94 \\
50 \cdot 8 \\
6 \cdot 2-183 \cdot 4\end{array}$ & $\begin{array}{l}3 \\
2 \cdot 57 \\
116 \cdot 7 \\
24 \cdot 1-341 \cdot 2\end{array}$ & $\begin{array}{l}3 \\
1 \cdot 61 \\
186 \cdot 3 \\
38 \cdot 4-544 \cdot 7\end{array}$ & $\begin{array}{l}1 \\
1 \cdot 34 \\
74 \cdot 6 \\
1.9-414 \cdot 4\end{array}$ \\
\hline $\begin{array}{l}\text { Non-Hodgkin's lymphopoietic cancer } \\
(200,202-207)\end{array}$ & $\begin{array}{l}\text { Obs } \\
\text { Exp } \\
\text { SMR } \\
95 \% \text { CI }\end{array}$ & $\begin{array}{l}2 \\
7 \cdot 34 \\
27 \cdot 2^{*} \\
3 \cdot 3-79 \cdot 5\end{array}$ & $\begin{array}{l}5 \\
4 \cdot 64 \\
107 \cdot 8 \\
34 \cdot 9-251.9\end{array}$ & $\begin{array}{l}4 \\
2 \cdot 89 \\
138 \cdot 4 \\
37 \cdot 7-354 \cdot 0\end{array}$ & $\begin{array}{l}4 \\
2 \cdot 23 \\
164 \cdot 6 \\
44 \cdot 8-421 \cdot 0\end{array}$ \\
\hline
\end{tabular}

*Statistically significant at the 0.05 level.

(Lymphatic and haematopoietic cancer includes non-Hodgkin's lymphoma, Hodgkin's disease, and leukaemia.) 
Table 12 Mantel-Haenszel relative risks and extension chi-squares for lymphatic and haematopoietic cancer, leukaemia, 3 non-Hodgkin's lymphoma, and non-Hodgkin's lymphopoietic cancer by cumulative occupational exposure to benzene, adjusted for age and race

\begin{tabular}{|c|c|c|c|c|c|}
\hline Cause of death (8th ICD) & $\begin{array}{l}\text { Cumulative exposure } \\
\text { (ppm-months) }\end{array}$ & Observed deaths & Relative risk & $\begin{array}{l}\text { Chi-square } \\
\text { for trend }\end{array}$ & p Value \\
\hline $\begin{array}{l}\text { Lymphatic and haematopoietic cancer } \\
(200-209)\end{array}$ & $\begin{array}{l}\text { Non-exposed } \\
<180 \\
180-719 \\
\geqslant 720\end{array}$ & $\begin{array}{l}3 \\
5 \\
5 \\
5\end{array}$ & $\begin{array}{l}1.00 \\
2 \cdot 10 \\
2.95 \\
3.93\end{array}$ & $5 \cdot 42^{*}$ & $0 \cdot 02$ \\
\hline Leukaemia and aleukaemia (204-207) & $\begin{array}{l}\text { Non-exposed } \\
<180 \\
180-719 \\
\geqslant 720\end{array}$ & $\begin{array}{l}0 \\
2 \\
1 \\
3\end{array}$ & Undefined & $6.46^{*}$ & 0.01 \\
\hline Non-Hodgkin`s lymphoma $(200,202,203)$ & $\begin{array}{l}\text { Non-exposed } \\
<180 \\
180-719 \\
\geqslant 720\end{array}$ & $\begin{array}{l}2 \\
3 \\
3 \\
1\end{array}$ & $\begin{array}{l}1 \cdot 00 \\
1 \cdot 40 \\
2 \cdot 23 \\
1 \cdot 07\end{array}$ & $0 \cdot 14$ & 0.71 \\
\hline $\begin{array}{l}\text { Non-Hodgkin's lymphopoietic cancer } \\
(200,202-207)\end{array}$ & $\begin{array}{l}\text { Non-exposed } \\
<180 \\
180-719 \\
\geqslant 720\end{array}$ & $\begin{array}{l}2 \\
5 \\
4 \\
4\end{array}$ & $\begin{array}{l}1 \cdot 00 \\
2 \cdot 71 \\
2 \cdot 96 \\
4 \cdot 12\end{array}$ & 3.64 & 0.06 \\
\hline
\end{tabular}

Table 13 Observed deaths by cause and SMRs for all cohort members exposed to benzene by maximum peak occupational exposure

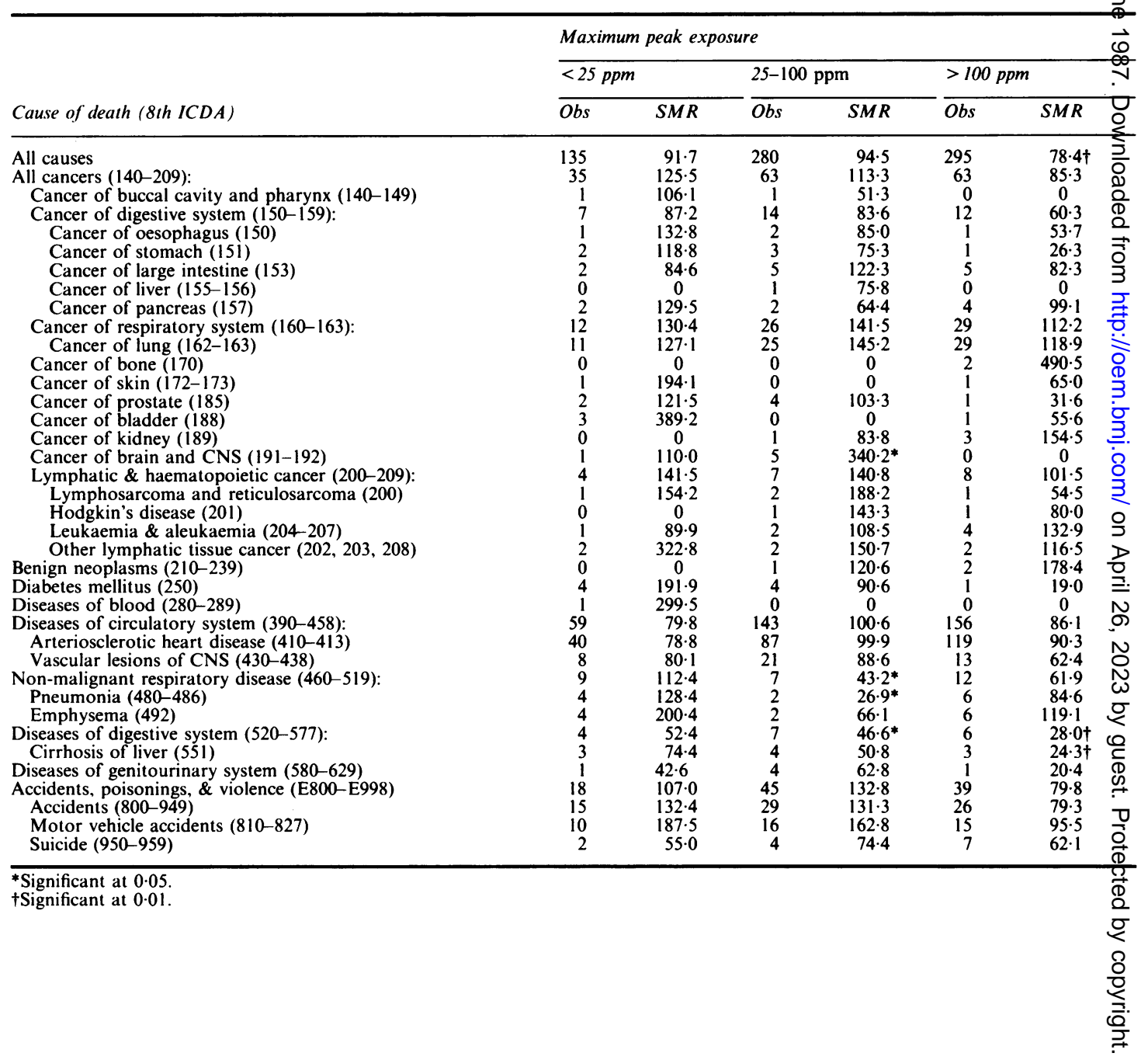


Table 14 Mantel-Haenszel relative risks and extension chi-squares for lymphatic and haematopoietic cancer, leukaemia, non-Hodgkin's lymphoma and non-Hodgkin's lymphopoietic cancer by cumulative occupational exposure to benzene, adjusted for age and race

\begin{tabular}{|c|c|c|c|c|c|}
\hline Cause of death $(8 \mathrm{th} I C D)$ & $\begin{array}{l}\text { Cumulative exposure } \\
\text { (ppm-months) }\end{array}$ & Observed deaths & Relative risk & $\begin{array}{l}\text { Chi-square } \\
\text { for trend }\end{array}$ & p Value \\
\hline $\begin{array}{l}\text { Lymphatic and haematopoietic cancer } \\
(200-209)\end{array}$ & $\begin{array}{l}\text { Non-exposed } \\
<180 \\
180-719 \\
\geqslant 720\end{array}$ & $\begin{array}{l}3 \\
5 \\
5 \\
5\end{array}$ & $\begin{array}{l}1 \cdot 00 \\
2 \cdot 10 \\
2 \cdot 95 \\
3 \cdot 93\end{array}$ & $5 \cdot 42^{*}$ & 0.02 \\
\hline Leukaemia and aleukaemia (204-207) & $\begin{array}{l}\text { Non-exposed } \\
<180 \\
180-719 \\
\geqslant 720\end{array}$ & $\begin{array}{l}0 \\
2 \\
1 \\
3\end{array}$ & Undefined & $6 \cdot 46^{*}$ & 0.01 \\
\hline Non-Hodgkin`s lymphoma $(200,202,203)$ & $\begin{array}{l}\text { Non-exposed } \\
<180 \\
180-719 \\
\geqslant 720\end{array}$ & $\begin{array}{l}2 \\
3 \\
3 \\
1\end{array}$ & $\begin{array}{l}1 \cdot 00 \\
1 \cdot 40 \\
2 \cdot 23 \\
1 \cdot 07\end{array}$ & $0 \cdot 14$ & $0 \cdot 71$ \\
\hline $\begin{array}{l}\text { Non-Hodgkin's lymphopoietic cancer } \\
(200,202-207)\end{array}$ & $\begin{array}{l}\text { Non-exposed } \\
<180 \\
180-719 \\
\geqslant 720\end{array}$ & $\begin{array}{l}2 \\
5 \\
4 \\
4\end{array}$ & $\begin{array}{l}1 \cdot 00 \\
2 \cdot 71 \\
2 \cdot 96 \\
4 \cdot 12\end{array}$ & $3 \cdot 64$ & 0.06 \\
\hline
\end{tabular}

*Statistically significant at the 0.05 level.

(Lymphatic and haematopoietic cancer includes non-Hodgkin's lymphoma, Hodgkin's disease, and leukaemia.)

Table 15 Mantel-Haenszel relative risk and chi-squares for lymphatic and haematopoietic cancer, leukaemia, non-Hodgkin's lymphoma, and non-Hodgkin's lymphopoietic cancer between chemical workers first occupationally exposed before and after age 30 , adjusted for age and race

\begin{tabular}{|c|c|c|c|c|c|}
\hline \multirow[b]{2}{*}{ Cause of death (8th ICD) } & \multicolumn{3}{|l|}{ Observed deaths } & \multirow{2}{*}{$\begin{array}{l}\text { Mantel-Haenszel } \\
\text { chi-square }\end{array}$} & \multirow[b]{2}{*}{ p Value } \\
\hline & First exposed $>30$ & First exposed $<30$ & Relative risk & & \\
\hline \multirow{5}{*}{$\begin{array}{l}\text { Lymphatic and haematopoietic } \\
\text { cancer }(200-209) \\
\text { Leukaemia and aleukaemia }(204-207) \\
\text { Non-Hodgkin's lymphoma }(200,202,203) \\
\text { Non-Hodgkin's lymphopoietic cancer } \\
(200,202-207)\end{array}$} & & & & & \\
\hline & 14 & 5 & $1 \cdot 51$ & 0.58 & 0.43 \\
\hline & 5 & 2 & 1.09 & 0.01 & 0.92 \\
\hline & 8 & 2 & $2 \cdot 52$ & $1 \cdot 33$ & 0.25 \\
\hline & 13 & 4 & $1 \cdot 72$ & 0.92 & 0.34 \\
\hline
\end{tabular}

(Lymphatic and haematopoietic cancer includes non-Hodgkin's lymphoma, Hodgkin's disease, and leukaemia.)

starting at $27 \cdot 2$ for the comparison group and rising to, in increasing cumulative exposure order, 107.8, $138 \cdot 4$, and $164 \cdot 6$.

Table 12 presents the Mantel-Haenszel RRs and the corresponding extension chi-squares for all lymphatic and haematopoietic cancer, leukaemia, nonHodgkin's lymphoma, and non-Hodgkin's lymphopoietic cancer, by cumulative exposure to benzene adjusted for age and race. For all lymphatic and haematopoietic cancer, the $R R$ rose steadily from 1.00 in the comparison group to 3.93 in the $\geqslant 720$ ppm-month group. The corresponding MantelHaenszel extension chi-square, which measured the significance of the upward trend, was $5 \cdot 42$, statistically significant ( $p=0.02$ ). For leukaemia, the RRs were infinitely large and undefined, since no death from leukaemia was observed for the occupationally nonexposed. The Mantel-Haenszel extension chi-square for leukaemia was $6 \cdot 46$, and the corresponding p value was $\mathbf{0 . 0 1 1}$. Therefore, dose response relations for leukaemia, and the broader category of lymphatic and haematopoietic cancer, were statistically significant. For non-Hodgkin's lymphoma, the RR rose from 1.00 in the comparison group to 2.23 in the $180-720$ ppm-months group and dropped to 1.07 for the $\geqslant 720$ ppm-months group; and there was no statistical evidence for a dose response relation. For non-Hodgkin's lymphopoietic cancer, the $\mathbf{R}$ rose steadily from 1.00 in the comparison group to 4.12 in the $\geqslant 720$ ppm-months group, but this dose response relation was of borderline statistical significance $(p=0.06)$.

ANALYSIS BY PEAK EXPOSURE

Each exposed job (intermittent or continuous) was characterised by a peak exposure. Cause specific SMRs were calculated for maximum peak exposure; $<25,25-100$, and $>100 \mathrm{ppm}$. In this calculation person-years were classified by the preceding maximum peak exposure. The cause specific SMRs by maximum peak exposure are presented in table 13. Again, to ensure similarity of age distributions when 
comparing indirectly adjusted SMRs, the percentage compositions of the maximum peak exposure groups were examined and were found to be generally similar.

The only obvious increasing dose-response relation from table 13 was that for leukaemia. Including the comparison group as the baseline, the leukaemia SMRs were $0,89.9,108 \cdot 5$, and 132.9 in order of rising maximum peak exposure. These SMRs, however, were based on few observed deaths.

Table 14 shows the analysis by maximum peak exposure using the Mantel-Haenszel extension procedure. For lymphatic and haematopoietic cancer, the RRs for all three peak exposure categories were around threefold when compared with the comparison group. The corresponding chi-square was $2 \cdot 10(\mathrm{p}=0.15)$. For leukaemia, the RRs were undefined, but the extension chi-square was 2.91 $(p=0 \cdot 09)$. For non-Hodgkin's lymphoma, the RRs did not show any pattern $(p=0 \cdot 81)$. For nonHodgkin's lymphopoietic cancer, the RRs for all three peak exposure categories were around three to fourfold, with no significant dose response relation. Thus no statistically significant trend was detected for either all lymphatic and haematopoietic cancer, leukaemia, non-Hodgkin's lymphoma, or non-Hodgkin's lymphopoietic cancer by maximum peak exposure to benzene.

\section{ANALYSIS BY AGE AT FIRST EXPOSURE}

Cause specific SMRs were calculated by age at first occupational exposure (before 30 and after 30). For lymphatic and haematopoietic cancer, the SMRs were 83.5 ( 5 observed) and 144.4 (14 observed) for the $<30$ and $\geqslant 30$ groups, respectively. The Mantel-Haenszel relative risk and chi-square were also calculated (table 15). Although the lymphopoietic cancer RR was 1.51 for those who were first occupationally exposed after age 30 when compared with those first occupationally exposed before 30 , the result was not statistically significant. For leukaemia, the SMRs were 89.9 (2 observed) and 133.7 ( 5 observed) for the $<30$ and $\geqslant 30$ groups respectively. The Mantel-Haenszel relative risk for leukaemia by age at first exposure was $1.09(p=0.92)$. For non-Hodgkin's lymphoma, the SMRs were 79.7 ( 2 observed) and 170.2 ( 8 observed) for the $<30$ and $\geqslant 30$ groups, respectively. The corresponding RR between the two groups was 2.52 $(p=0 \cdot 25)$. Similarly, there was no significant association between age at first occupational exposure and mortality risk due to non-Hodgkin's lymphopoietic cancer.

\section{Discussion and conclusion}

One interesting finding in this study was that analysis indicated that duration of exposure was not a partic- ularly sensitive parameter for quantification of eithe

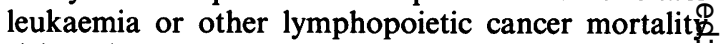
risk. When analysed by cumulative exposure ( $\mathrm{ppm}=$ months), however, statistically significant dose. response relations were detected for leukaemia an the broader category of all lymphopoietic cancer. Fo all lymphatic and haematopoietic cancer, those wite more than $720 \mathrm{ppm}$-months of exposure to benzen\& experienced nearly a fourfold risk $(R R=3.93)$ wheg compared with the occupationally unexposed group. The Mantel-Haenszel extension chi-square for the upward trend in lymphopoietic cancer was $5 \cdot 4 \overrightarrow{z_{t}}$ $(\mathrm{p}=0.02)$. For leukaemia, the Mantel-Haenszel chio square was $6.46(\mathrm{p}=0.01)$. For non-Hodgkin's lymळ phoma, no dose response relation was detected. Whe non-Hodgkin's lymphoma was combined with leup kaemia, however, a monotonic increasing trend was seen (those with $\geqslant 720 \mathrm{ppm}$-months experienced aw RR of 4.12), and this dose response relation approached statistical significance $(p=0.06)$. It should be pointed out that the concept of cumulative exposure (ppm-months) does not distinguish betweer concentration and duration of exposure to benzene $\mathbb{\nabla}$

When the data were analysed by maximum peal exposure to benzene, no significant dose response्u relation was identified. The findings in this study sugi gested that cumulative exposure (ppm-months), an not peak exposure, was the major parameter in quans tifying mortality risk from lymphopoietic cancer. Thi conclusion must be viewed with caution, however? since the analysis did not take frequency of peak exposure into consideration, owing to the limitation $\overrightarrow{\vec{s}}$ in peak exposure data and the methodologica difficulties in incorporating frequency or duration of peak exposure in analysis.

A review of the deaths from leukaemia in this stud. (table 16) indicated that none was from acute myeloi leukaemia, the cell type frequently associated witlo exposure to benzene in some of the previous stud? ies. $^{6-8}$ Four of the seven deaths from leukaemia iro this study were lymphatic leukaemia ( 1 acute, $\mathfrak{Z}$ chronic, and 1 unspecified), two were chronic myeloidg leukaemias, and one was acute leukaemia (unspecified). The proportion of lymphatic leu을. kaemias $(57 \%)$ was only slightly higher than the cor $\bar{N}$ responding figure $(44 \%)$ among men in the Third National Cancer Survey. ${ }^{9}$ On the other hand, othef studies have shown excess of lymphatic leukaemias among workers exposed to benzene ${ }^{10}$ and among petroleum refinery workers. ${ }^{11}$ This study did nof provide enough cases of leukaemia for a definitive analysis on leukaemia cell types.

Table 16 indicates that three deaths were due tor multiple myeloma. Among the four deaths from lym phopoietic cancer in the intermittent exposure group $\overrightarrow{\mathbb{Q}}$ two were from multiple myeloma. Decoufle et al $\overrightarrow{\mathbb{Q}}$ 
Table 16 Characteristics of 22 deaths from lymphatic and haematopoietic cancer

\begin{tabular}{|c|c|c|c|c|c|c|c|c|c|c|c|c|c|c|c|c|}
\hline Case & $\operatorname{Exp}$ & Plant & Race & $C O D$ & $D O B$ & $D O H$ & $\begin{array}{l}\text { First } \\
\text { exp }\end{array}$ & $D O T$ & $D O D$ & Age & $\begin{array}{l}\text { Yrs } \\
\exp \end{array}$ & $\begin{array}{l}\text { Yrs } \\
\text { Cont } \\
\text { exp }\end{array}$ & $\begin{array}{l}\text { ppm- } \\
\text { mos }\end{array}$ & $\begin{array}{l}\text { Max } \\
T W A\end{array}$ & $\begin{array}{l}\text { Max } \\
\text { peak }\end{array}$ & $\begin{array}{l}\text { Yrs } \\
\text { latency }\end{array}$ \\
\hline 1 & $\mathrm{C}$ & 3 & $\mathbf{W}$ & $202 \cdot 2$ & 1919 & $09 / 60$ & $09 / 60$ & $02 / 74$ & $02 / 74$ & $55 \cdot 0$ & $7 \cdot 2$ & $7 \cdot 2$ & 43 & L & L & 13.4 \\
\hline 2 & C & 4 & $\mathbf{N}$ & $201 \cdot X$ & 1935 & $04 / 60$ & $05 / 60$ & $04 / 70$ & $05 / 71$ & $36 \cdot 2$ & 1.8 & 1.6 & 192 & $\mathbf{H}$ & $\mathbf{M}$ & $11 \cdot 0$ \\
\hline 3 & C & 4 & W & $200 \cdot 0$ & 1902 & $06 / 42$ & $08 / 54$ & $02 / 57$ & $02 / 57$ & $54 \cdot 2$ & 0.9 & 0.2 & 14 & $\mathbf{M}$ & $\mathbf{M}$ & $2 \cdot 5$ \\
\hline 4 & $\mathrm{C}$ & 4 & $\mathbf{W}$ & $204 \cdot 1$ & 1920 & $04 / 55$ & $04 / 55$ & $08 / 69$ & $08 / 69$ & $48 \cdot 7$ & 9.9 & 9.9 & 524 & $\mathbf{H}$ & $\mathrm{H}$ & $14 \cdot 3$ \\
\hline 5 & $\mathrm{C}$ & 4 & $\mathbf{N}$ & 204.9 & 1897 & $08 / 28$ & $03 / 29$ & $10 / 55$ & $10 / 57$ & 59.9 & $14 \cdot 9$ & $14 \cdot 6$ & 1361 & $\mathbf{H}$ & $\mathrm{H}$ & 28.6 \\
\hline 6 & C & 4 & $\mathbf{W}$ & $205 \cdot 1$ & 1907 & $06 / 42$ & $11 / 42$ & $01 / 71$ & $09 / 71$ & $64 \cdot 2$ & 5.8 & 1.9 & 120 & $\mathbf{H}$ & $\mathbf{M}$ & 28.9 \\
\hline 7 & $\mathrm{C}$ & 4 & W & $202 \cdot 2$ & 1918 & $05 / 63$ & $05 / 63$ & $06 / 71$ & $12 / 73$ & 55.8 & $1 \cdot 3$ & $1 \cdot 3$ & 334 & H & $\mathbf{M}$ & $10 \cdot 6$ \\
\hline 8 & C & 4 & $\mathbf{N}$ & $203 \cdot X$ & 1907 & $03 / 40$ & $11 / 52$ & $05 / 63$ & $02 / 64$ & $57 \cdot 0$ & $2 \cdot 3$ & $2 \cdot 3$ & 14 & L & L & $11 \cdot 3$ \\
\hline 9 & C & 5 & W & $204 \cdot 0$ & 1905 & $11 / 25$ & $03 / 26$ & $12 / 67$ & $07 / 75$ & $70 \cdot 2$ & $12 \cdot 2$ & $12 \cdot 2$ & 731 & $\mathbf{M}$ & $\mathbf{M}$ & $49 \cdot 4$ \\
\hline 10 & $\mathrm{C}$ & 5 & W & $200 \cdot 0$ & 1900 & $07 / 33$ & $07 / 33$ & $12 / 62$ & $11 / 74$ & $74 \cdot 5$ & $26 \cdot 8$ & $26 \cdot 8$ & 1512 & $\mathbf{M}$ & $\mathbf{M}$ & $41 \cdot 4$ \\
\hline 11 & $\mathrm{C}$ & 5 & $\mathbf{W}$ & $205 \cdot 1$ & 1913 & $09 / 39$ & $04 / 56$ & $04 / 73$ & $03 / 75$ & $61 \cdot 8$ & $1 \cdot 2$ & $1 \cdot 2$ & 7 & L & L & 18.9 \\
\hline 12 & $\mathrm{C}$ & 6 & W & $207 \cdot 0$ & 1927 & $10 / 47$ & $10 / 47$ & $12 / 76$ & $06 / 77$ & $49 \cdot 6$ & $29 \cdot \overline{2}$ & $29 \cdot 2$ & 851 & $\mathbf{M}$ & $\mathbf{H}$ & $29 \cdot 7$ \\
\hline 13 & $\mathrm{C}$ & 2 & $\mathbf{W}$ & $202 \cdot 2$ & 1928 & $08 / 50$ & $10 / 50$ & $05 / 54$ & $08 / 72$ & $44 \cdot 4$ & $1 \cdot 7$ & $1 \cdot 7$ & 601 & $\mathbf{H}$ & $\mathbf{H}$ & $21 \cdot 9$ \\
\hline 14 & $\mathrm{C}$ & 2 & $\mathbf{W}$ & $201 \cdot X$ & 1910 & $10 / 40$ & $07 / 67$ & $07 / 74$ & $04 / 76$ & $65 \cdot 4$ & $7 \cdot 0$ & $7 \cdot 0$ & 2522 & $\mathrm{H}$ & $\mathbf{H}$ & $8 \cdot 7$ \\
\hline 15 & $\mathrm{C}$ & 7 & $\mathbf{W}$ & $200 \cdot 1$ & 1921 & $01 / 51$ & $06 / 54$ & $09 / 71$ & $11 / 71$ & $50 \cdot 1$ & 8.9 & 8.9 & 533 & $\mathbf{M}$ & $\mathbf{H}$ & $17 \cdot 4$ \\
\hline 16 & I & 1 & $\mathbf{W}$ & $204 \cdot 1$ & 1927 & $01 / 69$ & $01 / 69$ & $01 / 75$ & $01 / 75$ & 47.6 & $1 \cdot 4$ & & & & $\mathbf{H}$ & 6.0 \\
\hline 17 & I & 4 & $\mathbf{W}$ & $200 \cdot 0$ & 1894 & $10 / 23$ & $10 / 23$ & $10 / 59$ & $01 / 62$ & $67 \cdot 3$ & 35.4 & & & & $\mathbf{L}$ & $38 \cdot 2$ \\
\hline 18 & I & 4 & $\mathbf{N}$ & $203 \cdot X$ & 1913 & $06 / 37$ & $09 / 59$ & $10 / 76$ & $06 / 77$ & 64.0 & 6.6 & & & & $\mathbf{M}$ & $17 \cdot 8$ \\
\hline 19 & I & 4 & W & $203 \cdot X$ & 1913 & $03 / 49$ & $03 / 49$ & $08 / 69$ & $04 / 70$ & $56 \cdot 4$ & 20.4 & & & & $\mathbf{H}$ & $21 \cdot 1$ \\
\hline 20 & $\mathrm{U}$ & 4 & $\mathbf{W}$ & $201 \cdot X$ & 1892 & $09 / 33$ & $09 / 33$ & $10 / 56$ & $10 / 56$ & $64 \cdot 1$ & & & & & & \\
\hline 21 & $\mathrm{U}$ & 4 & $\mathbf{N}$ & $200 \cdot 1$ & 1884 & $12 / 42$ & $12 / 42$ & $07 / 50$ & $02 / 53$ & $68 \cdot 7$ & & & & & & \\
\hline 22 & $\mathrm{U}$ & 6 & W & $202 \cdot 2$ & 1905 & $09 / 47$ & $09 / 47$ & $06 / 70$ & $02 / 77$ & $71 \cdot 4$ & & & & & & \\
\hline
\end{tabular}

Key:

Exposure

$\mathrm{C}=$ Continuous

$\mathrm{I}=$ Intermittent

$\mathrm{U}=$ Unexposed

COD $=$ Cause of death

$\mathrm{DOH}=$ Date of hire

First Exp = Date of first exposure

DOT $=$ Date of termination/separation

DOD $=$ Date of death

Age $=$ Age at death

Yrs exp = Years of continuous and intermittent exposure

Yrs cont exp = Years of continuous exposure

Max TWA = Maximum eight hour TWA

Max peak = maximum peak exposure

based on a small cohort study, suggested a possible link between benzene and multiple myeloma. ${ }^{12}$ The standard computer program used in the present project did not provide an SMR for multiple myeloma, but a separate calculation indicated that the expected number (adjusted for age and race) of deaths from multiple myeloma based on United States male mortality was 0.56 . The multiple myeloma SMR for the intermittent exposure group was thus $357 \cdot 1$, with a $95 \%$ confidence interval of 43.2-1289.3 (not significant). This group was relatively small and could detect only risk ratios of at least 14 -fold with reasonable statistical power $(80 \%)$ at the 0.05 confidence level. Furthermore, the small number of deaths from multiple myeloma in the exposed groups and none in the comparison group did not lend the data to a direct comparison (Mantel-Haenszel procedure). Thus the study did not offer any firm data on the relation between exposure to benzene and multiple myeloma.

Table 16 gives a summary of the exposure histories of the deaths from lymphopoietic cancer. The cumulative exposure ranged from $7 \mathrm{ppm}$-months to 2522 ppm-months. Also listed in the table are the maximum eight hour TWAs. According to the work histories, three cases (case numbers 1, 8, and 11) were never exposed to an eight hour TWA of more than $1 \mathrm{ppm}$, and none of the cases was exposed to the "very high" eight hour TWA ( $>50 \mathrm{ppm})$. The maximum peak exposures are also listed for all the deaths from lymphopoietic cancer in the table. Four cases were never exposed to a peak level of more than $25 \mathrm{ppm}$.

Table 16 also shows the latent period for each death from lymphopoietic cancer. Among the continuously exposed, the average latent period for lymphopoietic cancer was 20.5 years, and among the intermittently exposed 20.8 years. The average latent period for leukaemia among all seven cases was $25 \cdot 1$ years. These latent periods were longer than those observed in previous studies.

In closing, it should be pointed out that there are several limitations in this study. Most are typical of a historical mortality study of industrial populations. Firstly, although both the percentage lost to follow up and the proportion of outstanding death certificates were low, $2 \cdot 3 \%$ and $2 \cdot 2 \%$ respectively, it was possible, but unlikely, that some deaths from lymphopoietic 
cancer might have been missed. This omission, however, could occur in both the exposed and unexposed groups.

Secondly, the results of cohort verification indicated an error rate of $0.8 \%$. Although this error rate was extremely small, the small number of individuals inadvertently excluded could subsequently have died from lymphopoietic cancer. Again, this could happen in both the exposed and the unexposed groups.

Thirdly, based on a $10 \%$ random sample of the cohort, coding accuracy was estimated at $97 \cdot 4 \%$. A small amount of coding error seems to be unavoidable in a large scale study such as this.

Fourthly, historical exposure levels for the early part of the study were limited for some of the plants. The problem was partially dealt with by the uniform task approach. This required the breakdown of exposed jobs into specific uniform tasks, for which benzene exposure levels could be estimated more readily. It should be pointed out that any misclassification in occupational exposure to benzene would tend to reduce and not increase the likelihood of detecting dose response relations. Furthermore, analyses by cumulative benzene exposure identified significant dose response relations only for leukaemia, as well as the broader category of all lymphopoietic cancer.

Fifthly, presumably those occupationally exposed to benzene were also exposed to other chemicals. This problem of concomitant exposures was partially dealt with by comparing them with occupationally nonexposed workers. Furthermore, the significant dose response relations between benzene and all lymphopoietic cancer or leukaemia would discredit any theory of concurrent exposures, unless the latter were some sort of benzene related "impurities," whose exposure levels were highly correlated with those of benzer.e. Employment history other than that with the participating plants was not available and not considered.

Sixthly, the cohort size was small for several specific analyses. For example, the dose response relation between leukaemia and cumulative exposure was based on a small number of deaths, and the statistical variabilities were considerable. Furthermore, the absence of any deaths from leukaemia in the comparison group presented a technical difficulty: relative risk for leukaemia between the occupationally exposed and unexposed groups was undefined. Similarly, the number of deaths due to non-Hodgkin's lymphoma was also small. Although the relative risk for non-Hodgkin's lymphoma for white male workers in the continuous exposure group was fivefold, it did not reach statistical significance $(p=0 \cdot 12)$. Also, as discussed earlier, the study was too small to offer any firm data on the relation between exposure to benzene and multiple myeloma. The final study cohort sufferec $\$$ from the withdrawal of two major plants from the study, and a reduction of cohort members, as well as: a loss of person-years due to the unforeseen incom $\stackrel{P}{P}$ pleteness of employment records before 1957 at tw other plants. The presence of dose response relation partially ameliorates the problem of small numbers.

Seventhly, there was no practical means of checking the comparability of the exposed and the comparisom groups with regard to some non-occupational risk factors. In this study the internal comparison group was simply those workers from the same facilities wh ${ }^{-}$ were not occupationally exposed to benzene. Dat? collection and death ascertainment for both group\$ were conducted in an identical manner. We have examined the comparability of several demographis and occupational parameters (such as year of birtis and age at hire), and found no major differences $s_{\infty}$ although the duration of employment of the com ${ }_{0}^{0}$ parison group was somewhat shorter than that of the exposed. There were more unobtained death certificates in the comparison group, but it seemees unlikely that these minor differences could accoun for the observed mortality difference in lymphopoieti $\vec{E}$ cancer. Although one may raise the question regardơ ing the comparability in starting person-years of the exposed and comparison groups, since the early yearo of employment are generally associated with a greate healthy worker effect. Calculations showed that the delay in starting person-years in the exposed grouks was only $2 \cdot 14$ years. Although any difference in age and race was adjusted in the analysis, the possibilit $\vec{D}$ of some unknown confounding factors existing between the two groups remained. In controlled clin ical trials such confounding factors can be eliminate by randomisation. In observational studies such a this one, however, randomisation is not feasibles Based on data available from this study, we can onlo say that there was no evidence to suspect that suct. confounding factors existed. The dose response relations further discredit any theory of unknow confounding factors between the exposed and the comparison groups, since various levels of cumulativo exposure within the exposed group were compared. In. this regard it should be noted that the overall SMR for the occupationally exposed groups and the com parison group were not dissimilar (86.6 v 75.2). In facts the $\geqslant 720 \mathrm{ppm}$-months group experienced the lowest overall mortality (SMR $=63.5, \mathrm{p}<0.01)$, indicating that this group, although with the highest SMR for all lymphopoietic cancer and leukaemia, was not otherwise generally unhealthy.

Finally, being a mortality study, the investigationo not only inherited all the problems associated wit $\bar{\Phi}$ death certificates (diagnostic accuracy, for example\$

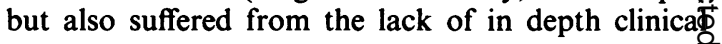


information.

Despite these limitations, the study has shown that chemical workers occupationally exposed to benzene experienced significant mortality excess from leukaemia, as well as the broader category of all lymphatic and haematopoietic cancer, when compared with chemical workers who were not occupationally exposed to benzene. This result of leukaemia excess was consistent with some of the findings of previous epidemiological reports, but the cell types were not typical of those reported in many earlier studies. The data further show significant dose response relations between cumulative benzene exposure and excess mortality from leukaemia and the broader category of all lymphatic and haematopoietic cancer. Although significant dose response relations were established, the precise shape of the dose-response curves was less definite due to the variability of the available data (particularly the estimated historical data). As such, although the dose response relation has added strength to the association between exposure to benzene and leukaemia and lymphatic and haematopoietic cancer, the estimated historical industrial hygiene data were not precise enough for absolute quantitative risk assessment.

I express my appreciation to the Chemical Manufacturers Association (CMA) and to the eighteen companies which comprise the CMA Benzene Panel sponsoring the study. I especially thank the six companies whose plants provided the cohorts for this study and whose personnel provided the basic data and continuing help. Finally, I recognise the valuable efforts of Carol Stack, the CMA benzene program manager. Dr Abraham $M$ Lilienfeld served as a consultant to this project.
Requests for reprints to: Dr Otto Wong, Environmental Health Association, Inc., 520 Third Street, Suite 208, Oakland, CA 94607.

\section{References}

1 Wong $O$. An industry wide mortality study of chemical workers occupationally exposed to benzene. I. General results. Br J Ind Med 1987;44:365-81.

2 March GM, Preininger M. OCMAP: a user-oriented occupational cohort mortality analysis program. American Statistician 1980;34:254.

3 Mantel N, Haenszel W. Statistical aspects of the analysis of data from retrospective studies of disease. JNCI 1959;22:719-48.

4 Mantel N. Chi-square tests with one degree of freedom: extension of the Mangel-Haenszel procedure. Journal of the American Statistical Association 1963;59:690-700.

5 Esmen N. Retrospective industrial hygiene surveys. Am Ind Hyg Assoc J 1979;40:58-65.

6 Aksoy M. Benzene and leukaemia. Lancet 1978;i:441.

7 Ott MG, Townsend JC, Fishbeck WA, Langner RA. Mortality among individuals occupationally exposed to benzene. Arch Environ Health 1978;33:3-10.

8 Rinsky RA, Young RJ, Smith AB. Leukemia in benzene workers. Am J Ind Med 1981;2:217-45.

9 Cutler SJ, Young JL. Third national cancer survey: incidence data. Washington: US Department of Health Education and Welfare, 1975:75-787. (DHEW publication No (NIH) [1975].)

10 Linos A, Kyle RA, O'Fallon WM, Kurland LT. A case-control study of occupational exposures and leukaemia. Int J Epidemiol 1980;9:131-5.

11 Schottenfeld D, Warshauer ME, Zauber AG, Meikle JG, Hart BR. A prospective study of morbidity and mortality in petroleum industry employees in the United States - a preliminary report. (Banbury report No 9.) Quantification of occupational cancer. Washington: Cold Spring Harbor Laboratory, 1981:247-65.

12 Decoufle P, Blattner WA, Blair A. Mortality among chemical workers exposed to benzene and other agents. Environ Res 1983;30:16-25. 